Fetner, R. H. \& Ingols, R. S. (1956). J. gen. Microbiol. 15, 381-385

\title{
A Comparison of the Bactericidal Activity of Ozone and Chlorine against Escherichia coli at $1^{\circ}$
}

\author{
By R. H. FETNER aND R. S. INGOLS \\ Engineering Experiment Station, Georgia Institute of Technology, Atlanta, \\ Georgia, U.S.A.
}

\begin{abstract}
SUMMARY : The bactericidal effects of ozone solutions were tested against Escherichia coli suspensions at $1^{\circ}$, and the lethal concentration was found to be that quantity of ozone necessary to produce a detectable residue in the suspension; under the conditions of our experiments this was $0.4-0.5 \mathrm{mg}$./l. A comparison of the bactericidal activity of chlorine under similar conditions emphasized the different modes of action of the two agents.
\end{abstract}

Quantitative studies on the antibacterial activity of ozone are difficult because of the instability of ozone solutions. The decomposition of ozone in solution is described as occurring in a stepwise fashion, producing in turn hydroperoxyl and hydroxyl radicles (Adler \& Hill, 1950), both of which exhibit considerable biological activity. The decomposition process is temperature dependent and is catalysed by hydroxyl ion (Adler \& Hill, 1950; Stumm, 1954). The usual process of bubbling ozone through a bacterial suspension and then measuring the total oxidizing residue iodometrically fails to give an accurate determination of the amount of ozone present. Adler \& Hill (1950) pointed out, for example, that KI solutions measure the total oxidizable capacity rather than the amount of ozone only. It was deemed necessary that before biological investigations, a study should be made on the chemistry and kinetics of ozone solutions and an evaluation made on the analytical techniques of ozone determination under conditions appropriate to this problem. The detailed results of these studies were presented elsewhere (Ingols, Fetner \& Eberhardt, 1956); it was found that ozone solutions at $1^{\circ}$ and $\mathrm{pH} 2\left(0.01 \mathrm{~N}-\mathrm{H}_{2} \mathrm{SO}_{4}\right)$ are relatively stable, showing little decomposition over a period of $8 \mathrm{hr}$. The analytical method of choice for ozone determination in such solutions is the ferrous ion method, in which ferrous ion (as $\left.\mathrm{Fe}\left(\mathrm{NH}_{4}\right)_{2}\left(\mathrm{SO}_{4}\right)_{2} \cdot 6 \mathrm{H}_{2} \mathrm{O}\right)$ is oxidized to the ferric state and then the excess of ferrous ion titrated with potassium permanganate. It was decided that by treating bacterial suspensions with dilutions of such stable solutions of ozone at ( $1^{\circ}$ and $\left.\mathrm{pH} 2\right)$, a more definite interpretation could be made of the activity of ozone itself. To obtain additional information about ozone activity at the concentrations of greatest biological interest, oxidation-reduction $(O / R)$ potentials of buffered bacterial suspension were determined after the addition of various amounts of ozone.

\section{METHODS}

The organisms (strain ' $B$ ' obtained from Professor $\mathbf{H}$. Wycoff, a representative strain which behaved biochemically as a typical member of Escherichia coli), were grown in nutrient broth (Difco) at $37^{\circ}$ for $18 \mathrm{hr}$. Test suspensions 
were diluted to contain $c .5 \times 10^{4}$ viable organisms $/ \mathrm{ml}$. in $100 \mathrm{ml}$. of $0.01 \mathrm{M}$ phosphate buffer ( $\mathrm{pH} 6 \cdot 8$ ), chilled to $1^{\circ}(30-45 \mathrm{~min}$.), and treated with ozone or chlorine (Zonite) from stock solutions. After the desired period of contact the reaction was stopped by the addition of excess sodium thiosulphate $(5.0 \mathrm{ml} .0 \cdot 1 \mathrm{~N})$ the solutions returned to room temperature and plate counts made according to standard procedures (American Public Health Association, 1955). The ozone was generated in a laboratory ozonator (Welsbach Co.; Philadelphia; Model T-23) using commercial oxygen as the gas supply. The ozone + oxygen mixture was bubbled through $\left(0 \cdot 1 \mathrm{~N}-\mathrm{H}_{2} \mathrm{SO}_{4}\right)$ solution in a gas scrubber. The ozonator, oxygen gas cylinder and the water cooler for the ozonator were located in a refrigerated room where all the low-temperature work was performed. Glass-distilled and de-ionized water (specific conductance at $25^{\circ}=0.94 \times 10^{-6}$ reciprocal ohms) was used in all experimental work.

The ferrous-ferric ion analytical technique (Ingols et al. 1956) was used to analyse the ozone concentration of the stock solution. Enough ferrous ammonium sulphate was added to measured samples of the ozone solution to bring $100 \mathrm{ml}$. of it to $c .0 \cdot 005 \mathrm{~N}$ and the non-oxidized ferrous ion was then titrated with $0 \cdot 1 \mathrm{~N}$-potassium permanganate. Chlorine concentrations were determined iodometrically according to the methods prescribed by the American Public Health Association (1955).

Oxidation-reduction potential measurements were made with a platinumcalomel electrode system connected to a Beckmann (model H-2) pH meter. In these experiments buffered bacterial suspensions were used which were similar to those in the dose/contact time experiments. To these bacterial suspensions, successive equal volumes of an ozone solution were added at $1^{\circ}$, and the $\mathrm{O} / \mathrm{R}$ potential $(\mathrm{mV})$ measured.

\section{RESULTS}

Table 1 summarizes the information obtained on the bacterial properties of ozone. This information reveals that: (1) The bactericidal concentration of ozone for the Escherichia coii strain used under these experimental conditions ( $<1 \%$ survivors) was between 0.4 and $0.5 \mathrm{mg} . / 1$; (2) the concentration of ozone necessary to effect this kill had a very critical value; (3) at this con-

Table 1. Survival of Escherichia coli in different concentrations of ozone in solution after various contact times at $1^{\circ}$

\begin{tabular}{|c|c|c|c|c|c|c|}
\hline \multirow[b]{2}{*}{$\begin{array}{c}\text { Initial } \mathrm{O}_{3} \\
\text { concentration } \\
\text { (mg./l.) }\end{array}$} & \multicolumn{6}{|c|}{ Period of exposure (min.) } \\
\hline & 1 & 2 & $\begin{array}{c}\mathbf{4} \\
\text { Sur }\end{array}$ & $\begin{array}{c}8 \\
\%)\end{array}$ & 16 & 32 \\
\hline 1.00 & $<1$ & $<1$ & $<1$ & $<1$ & - & - \\
\hline $0 \cdot 75$ & $<1$ & $<1$ & $<1$ & $<1$ & $<1$ & $<1$ \\
\hline 0.63 & $<1$ & $<1$ & $<1$ & $<1$ & $<1$ & $<1$ \\
\hline 0.53 & $<1$ & $<1$ & $<1$ & $<1$ & $<1$ & $<1$ \\
\hline $0 \cdot 42$ & 75 & $<1$ & 71 & $<1$ & 73 & 46 \\
\hline $\mathbf{0} \cdot \mathbf{3 1}$ & 96 & 97 & 74 & 70 & 92 & - \\
\hline $0 \cdot 21$ & $\mathbf{3 3}$ & 82 & 99 & 99 & 79 & 69 \\
\hline
\end{tabular}


centration, a contact time greater than $1 \mathrm{~min}$. was not necessary; (4) at ozone concentrations near or just smaller than lethal, the bactericidal action was irregular, probably an expression of the instability of ozone solutions.

The results of the chlorination studies are given in Table 2 , which indicates that chlorine $\left(\right.$ as $\mathrm{Cl}_{2}$ ) at a concentration of $0.25-0.30 \mathrm{mg}$./l. was effective at $1^{\circ}$ and $\mathrm{pH} 6.8$ in decreasing the bacterial count to $1 \%$ of the control in 1 to $10 \mathrm{~min}$.

Table 2. Survival of Escherichia coli in different concentrations of chlorine in solution at $1^{\circ}$ after various contact times

\begin{tabular}{|c|c|c|c|c|c|c|c|}
\hline \multirow{2}{*}{$\begin{array}{c}\text { Initial } \\
\text { concentration } \\
\text { of chlorine } \\
\text { (mg./l.) }\end{array}$} & \multicolumn{7}{|c|}{ Period of exposure (min.) } \\
\hline & \multicolumn{7}{|c|}{ Survival $(\%)$} \\
\hline $1 \cdot 10$ & $<1$ & $<1$ & $<1$ & $<1$ & $<1$ & $<1$ & $<1$ \\
\hline 0.52 & $<1$ & $<1$ & $<1$ & $<1$ & $<1$ & $<1$ & $<1$ \\
\hline $0 \cdot 35$ & $1 \cdot 5$ & $<1$ & $<1$ & $<1$ & $<1$ & $<1$ & $<1$ \\
\hline 0.27 & $\mathbf{2 \cdot 0}$ & $1 \cdot 5$ & $1 \cdot 6$ & $1 \cdot 2$ & $1 \cdot 0$ & $<1$ & $<1$ \\
\hline $0 \cdot 25$ & 24 & 19 & 12 & 13 & 8 & 7 & 5 \\
\hline $0 \cdot 17$ & 70 & 53 & 39 & 24 & 15 & 4 & $<1$ \\
\hline $0 \cdot 10$ & 87 & 66 & 64 & 46 & 46 & 45 & 40 \\
\hline
\end{tabular}

Fig. 1 emphasizes the difference between the bactericidal activities of ozone and chlorine. When the surviving fraction of bacteria is plotted against concentration, with a common period of exposure to the bactericidal agents, the chlorination results show a typical logarithmic curve, whereas ozone produced an immediate complete kill at the critical concentration.

To obtain additional information about ozone activity at the concentrations of greatest biological interest, oxidation-reduction $(\mathrm{O} / \mathrm{R})$ potentials of buffered bacterial suspensions were determined after the addition of various amounts of ozone. It was reasoned that the $\mathrm{O} / \mathrm{R}$ potential at or close to the lethal concentration would exhibit a demonstrable change indicative of the corresponding activity. Fig. 2 presents the results of the experiment; it can be seen that there was a sharp break in the $O / R$ potential at an ozone concentration comparable to the lethal concentration in the dosige contact time experiments. A differential plot of the same data emphasizes this information (Fig. 3).

\section{DISCUSSION}

The lethal concentration of ozone for the strain of Escherichia coli (0.4$0.5 \mathrm{mg}$./l.) under these experimental conditions is higher than the values obtained by other workers (Bringmann, 1954; Leiguarda, Peso \& Polazzolo, 1949), who determined the ozone residue as total oxidizable constituents remaining after bubbling ozone through a test solution. This slightly higher ozone value may be the result of temperature dependency or of our use of the dose required rather than residue accumulated. Each particular test solution can be assumed to have a certain ozone consumption 
A comparison of the bactericidal activity of ozone and chlorine emphasizes the different modes of action of the two agents. The surviving fraction of chlorine-treated bacteria decreases in geometric progression as a function of time or concentration (Fig. 1). Ozone, on the other hand, showed an all-or-

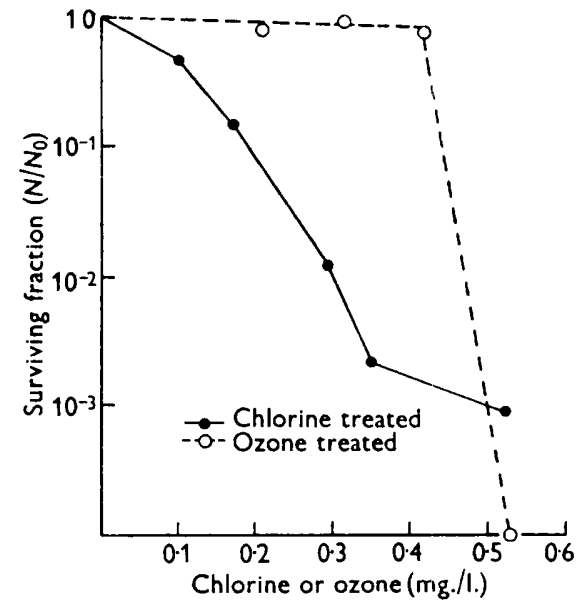

Fig. 1. Surviving fraction of Escherichia coli as a function of chlorine or ozone concentration; contact time $16 \mathrm{~min}$. at $1^{\circ}$.

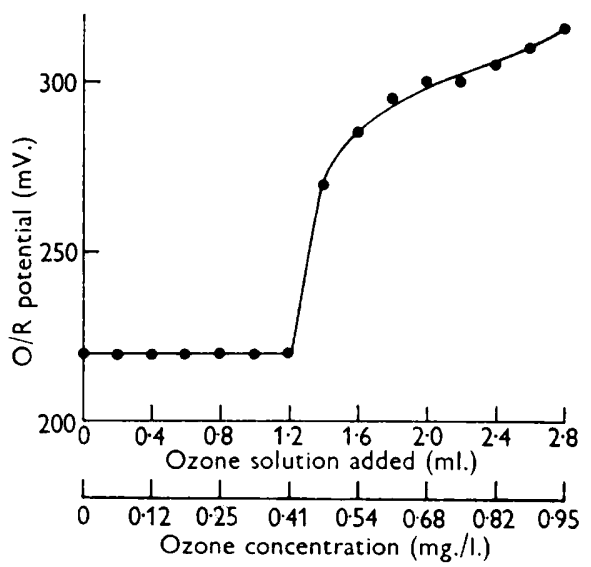

Fig. 2. Oxidation-reduction potential of suspensions with addition of various amounts of ozone solution. (Escherichia coli buffered suspension at $1^{\circ}$ and $\mathrm{pH} 6 \cdot 8$.)

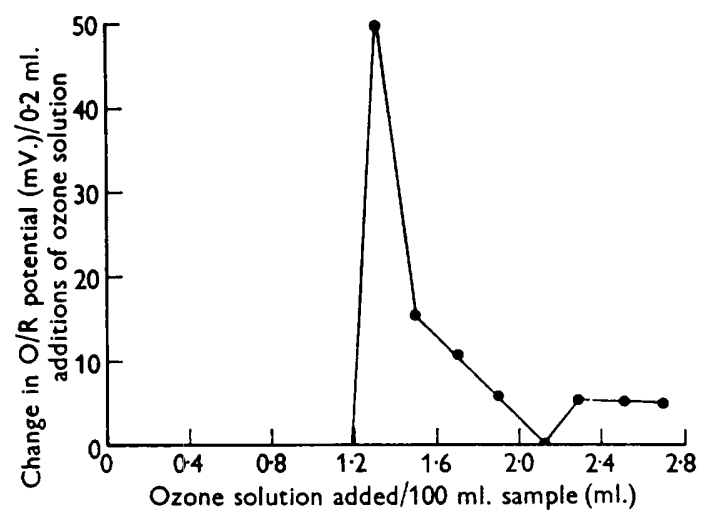

Fig. 3. Differential plot of data of Fig. 2.

none type of effect within the contact of $1 \mathrm{~min}$.; there was no effect of the ozone below a certain critical concentration and above this concentration there were no detectable survivors. We have determined that this critical concentration represents that quantity of ozone necessary to produce a detectable residue in suspension. This information tends to support the theory of Bringmann (1954) that ozone acts as a general protoplasmic oxidant. 
This work was performed under contract no. AF-18(600)-1376 of the Arctic Aeromedical Laboratory, Air Research and Development Command, United States Air Force.

\section{REFERENCES}

Adler, M. G. \& Hill, G. R. (1950). The kinetics and mechanism of hydroxide iron catalyzed ozone decomposition in aqueous solution. J. Amer. chem. Soc. 72, 1884.

Bringmans, G. (1954). Die Wirkung von Ozon auf Organismen des Trinkwassers. Z. Hyg, InfektKr. 139, 130.

Ingols, R. S., Fetner, R. H. \& Eberhardt, W. H. (1956). Determining ozone in solution. Anal. Chem. (In the Press.)

Leiguarda, R. H., Peso, O. A. \& Polazzolo, A. Z. R. (1949). Accion bactericida del ozons. Ann. Ass. Quimica Argentina, 37, 165.

Standard Methods for the Examination of Water, Sewage, and Industrial Wastes (1955). 10th ed. American Public Health Assoc. Baltimore: Waverly Press.

Sтuмm, W. (1954). Der Zerfall von Ozon in wässriger Lösung. Helv. chim. acta, 37 , 773.

(Received 1 May 1956) 